\title{
The Nigerian Leadership Question and the Quest for National Development: The Elitist Perspective
}

\author{
Etebom John Monday, PhD \\ Department of Local Government and Development Studies \\ Obafemi Awolowo University \\ Ile Ife, Nigeria \\ E-mail: etebomjohn@gmail.com \\ Odekunle Jamiu Abiola, \\ Department of Political Science \\ Obafemi Awolowo University \\ Ile Ife, Nigeria \\ Aminu Ridwan Adewale \\ Department of Political Science \\ Obafemi Awolowo University \\ Ile Ife, Nigeria \\ Olatunji Moshood Abiodun \\ Department of Political Science and Public Administration \\ Fountain University \\ Osogbo, Nigeria
}

Received: Aug. 21, 2019 Accepted: February 24, 2020 Online published: Mar. 2, 2020

doi:10.5296/jpag.v10i1.15316 URL: https://doi.org/10.5296/jpag.v10i1.15316 


\section{Abstract}

The roles of leaders in any given organized society are vital for the development and sustenance of such society. Leaders are expected to have a clear vision and well articulated agenda on how to ensure that followers key into this agenda using the instrument of mass mobilization and effective communication. For Nigeria getting leadership right has been a recurring debate since its independence in 1960. The country has had more of sectional leaders, self seeking and dictatorship than nationalists as leaders. Nigeria political landscape is dominated by the governing elite who share similar orientation on the need to preserve the political system for continuous perpetuation of control over the polity. This study examines the Nigerian leadership question within the framework of the elite theory. The paper analyzed the applicability of the elite theory in the face of Nigeria leadership question and its quest for development. It further examined whether the elite theory has been misapplied in solving the Nigerian challenges and made recommendations. The study found out that the elite theory is applicable in explaining the Nigerian leadership question. The study adopted both primary and secondary sources of data. The data collected were analyzed using content analysis and descriptive methods. The study revealed that corruptions, self serving policies, nepotism, weak institutions, constitutional abuse among others are the major problems affecting leadership in Nigeria.

Keywords: elitist, leadership question, governing elite, leadership recruitment, leadership regeneration

\section{Introduction}

The insatiable quest for quality leadership to pilot the affairs of emerging nations has been the major preoccupation of many contemporary social theorists. The search for effective leadership with proven integrity and sound leadership qualities had led to postulations of theories by various scholars and political thinkers. One of the theories that have gained wide acceptance is the elite theory because of it exposition of the various actors and their roles in a political system (Mbah, 2012).

One of the major issue that scholars, politicians and practitioners have persistently seek to solve in Nigeria since her independence in 1960 is the leadership question. This view was buttressed by Obah-Akpowoghaha (2013), when he argued that the leadership tussles among the three major ethnic groups led to the collapse of the First Republic and served as an invitation to the military in politics; which according to him instigated the civil war in the country. The intervention of the military in Nigerian politics (coups and counter coups) is premised on the failure of leadership in the country. The military and candidates of political parties have used the issue of failure of leadership, corruption, economic degradation and societal inequality as a basis for political intervention and campaign respectively. Nigeria witnessed more of military rule than democratic governance in its first $50^{\text {th }}$ years after independence. These military coups and counter coups all alluded to failure of leadership either by civilian or military governments. Also, the failure of the ruling party (People Democratic Party) in Nigeria since her returned to democratic rule in 1999 despite its boost to stay in power for 60 years and it subsequent rejections at the poll by Nigerian electorates in 
2015 was premised on bad leadership (Etebom, 2019).

The elite theory is premised on the notion of social inequality and inevitability of social stratification in any organized political setting (Akindele, 1999). Elitism emphasized the impossibility of egalitarianism by claiming the inevitability of authoritarianism and stratification in any human society. The main kernel of elitism as portrayed by Pareto and Mosca who were undeniably the foremost exponents of classical elitism is that "in any society there always exist a minority of the population which takes the major decisions and the majority who follows (Mbah, 2012). The efficacy of elitism as a theory for justifying leadership in Nigeria cannot be overemphasized. Nigerian political landscape since Independence in 1960 has been dominated by the political, military and religious elites who share similar orientation, social values and consensus on the need to preserve the political system for the continuous protection of their insatiable quest for political power and dominance. (Ogunmilade, Nwoko \& Akhigbe, 2017; Etebom, 2019). These leadership failures has affected inversely national development which is expressed by the myriad of challenges facing the country ranging from insecurity, ethnic agitations, high level of unemployment, corruption, poor infrastructural facilities, high level of poverty and many more.

This study adopted both primary and secondary data. The primary data are compilations of the study lead author for his private library over the years as a political scientist; while the secondary data were sourced from relevant books, academic journals, official documents and internet materials. The data gathered were analyzed using content analysis and descriptive methods. The study examined the persistent leadership challenges bedeviling Nigerian state from an elitist approach. It provided a brief history of Nigerian leadership trends since Independence in 1960 till date. The study further analyzed the various theoretical perspectives of the elite theory in an attempt to addressing the Nigeria leadership question and it quest for development; and made recommendations for effective leadership which will engender development in the country.

\section{Conceptual Clarification}

\section{Elite}

In its general sense, the elite denote a group of persons who in any society holds positions of eminence. In politics, it denotes specifically those who exercise preponderant political influence in a community (Mbah, 2012). He posited that, the elite are differently designated as the power elite, the ruling class, political class, the establishment and the governing minority. The ruling elite are known by high degree of elite consciousness or organization which they possess. They may be a caste, a ruling class who occupy a position of authority and relevance in the society (Varma, 2005). In Nigeria, elites are prevalent in different sectors of our social, political and economic life and are designated as leaders of thought, political heavy weight, captain of industries, retires military generals, national leaders, political office holders etc. who in general features prominently in socio-political affairs. 


\section{Macrothink}

Journal of Public Administration and Governance

ISSN 2161-7104

2020, Vol. 10, No. 1

\section{Leadership}

Leadership can be understood either as a pattern of behavior, or as a personal quality. As a pattern of behavior, leadership is the influence exerted by an individual or group over a larger body to organize or direct its efforts towards the achievement of desired goals. As a personal attribute, leadership refers to the character traits that enable the leader to exert influence over others (Heywood, 2013)

The Oxford Advance Learner Dictionary defined leadership from a behavioral perspective as a person or group of persons who lead a group of people especially the head of a country, an organization etc. From these aforementioned definitions of leadership, it involves establishing a clear vision, sharing the vision with others so that they will follow willingly, providing the information, knowledge and methods to actualize the vision, coordinate and balance the conflicting interests of all members and stakeholders for the general good. A leader steps up in times of crisis; and is able to thinks and act creatively in difficult situations. Quality leadership traits can be learned and enhanced through coaching or mentoring. Central to good leadership traits are effective communication and selfless service. A leader of an organization, state or country has the confidence of the followers by making them believe and know they are in charge.

\section{Functions of Leadership}

- Inspire Trust: A good leader must be able to inspire trust. The followers should be able to trust without any doubt his ability to demonstrate good character, competence and deliver.

- Create Vision: A good leader should be able to clearly define the direction to follow in achieving set goals.

- Execute Strategy: Consistently achieve results with and through others using discipline process.

- Coach Potential: Unleash the ability of each person on your team to improve performance, solve problems and grow their careers.

- Good Management: A leader should be able to manage human and material resources effectively to achieve maximum output at all times.

In politics, leadership denotes a group of people who are trusted with running the machinery of the state. Political powers are vested in them and they are expected to keep the country as a united and indivisible political entity. They are usually a minority group within the society and derive their legitimacy through a process of recruitment such as election, selection, appointment, promotion etc.

\section{Concepts Contextualization}

The elite theory is a direct response to the inability of socialist and marxist postulations of egalitarianism and classless society to come to pass within western society. The idea is that, there is in every society a minority of the population which takes the major decisions and those decisions have political implication. Akindele (1999) \& Mbah (2012) 
The central thesis of the classical elite theory can be summed as follows;

1. Society is divided into two groups; the few who rule and the majority who are ruled

2. The few who govern are not typical of the masses that are governed.

3. Only non elites who have accepted the basic elite consensus can be admitted into the governing circle.

4. Elite share consensus on behalf of the basic values of the social system and the preservation of the system.

5. Public policy does not reflect demands of the masses but rather the prevailing values of the elite.

6. Active elites are subjected to relatively the direct influence from the apathetic masses that are to say, elite influence the masses more than the masses influence the elite.

Using these assumptions as the basis of analysis, elite theorists have constantly argued that the governing minority in the society gain its dominance by means beyond ordinary elections. The appearance of democratic majority over the minority is deceptive because electoral victory is not gained by open democratic means alone but by others means that ranges from revolutionary overthrow of dominant group as well as monopolistic control of crucial reproductive resources Akindele (1999).

The elites theorists commonly shared the belief that the supremacy of the elites over the majority in the society is inevitable, hence the assumption that the cumulative quality of the members of the elites is potentially capable of preserving their dominance over the masses; this makes the elite a coherent united and self conscious group in any society. Moreover, the social background and organization of the elite itself is the breeding force of elite unity. They particularly attribute this to the cohesiveness of elite which to them represents the main strength underlying their power.

In propounding this theory, classical elite theory asserted that power is cumulative because it gives access to more power. They further maintained that cumulative effect of power and other opportunities will always maintain the dominant position of the elite from generation to generation. The existence of this situation will continue to widen the stratification gap between the elites and other group in the society.

\section{Perspectives of Classical Elite Theorists}

The origins of the elite theory, which came under active discussion of social scientists in the United States in the fifties economists (Schumpeter), political scientists (Lasswell) as well as sociologists (C. Wright Mills) can be traced back to the writings of a number of European thinkers in the years preceding the growth of fascism-particularly to Vilfredo Pareto and Gaetano Mosca, both Italians, as well as Roberto Michels.

\section{Vilfredo Pareto (1848-1923)}

Pareto believed that every society is ruled by a minority that possesses the qualities necessary 
for its accession to full social and political power. Those who get on top are always the best. They are known as the elite. The elites consist of those successful persons who rise to the top in every occupation and stratum of society: there is elite of lawyers, an elite of mechanics and even an elite of thieves and an elite of prostitutes. Pareto also believed that elites in different occupations and strata of society generally come from the same class: those who are wealthy also' are intelligent, have an aptitude for mathematics, musical talent, moral character, etc. Society, thus, consists, according to Pareto, of two classes: a higher stratum, the elite, which are divided into governing elite, and non-governing elite, and a lower stratum, the non-elite. Pareto's focus of enquiry was the governing elite which, he believed, rules by a mixture of force and cunning. It is force, however, which he regards as predominating.

\section{Roberto Michels (1876-1936)}

The name of Roberto Michels is associated with what is known as the "iron law of oligarchy", which he declares as "one of the iron laws of history, from which the most democratic modern societies and, within those societies, the most advanced parties, have been unable' to escape". The primary factor supporting this law is the element, of organisation. No movement or party can hope to succeed in modern times without organisation. "Organisation" is simply another way of spelling "oligarchy". "Immanent oligarchical tendencies", writes Michels, "exist in every kind of human organization which strives for the attainment of definite ends.

Oligarchy is a preordained form of the common life of great social aggregates. The majority of human beings, in a condition of eternal tutelage, are predestined to submit to the dominion of a small minority. Leadership is a necessary phenomenon in every form of social life. All order and civilization must exhibit aristocratic features". As a movement or party grows in size, more and more functions have to be delegated to an inner circle of leaders, and, in course of time, the members of the organization are rendered less competent to direct and control them, as a result of which the officers acquire great freedom of action and a vested interest in their position. They cling desperately to their new powers and privileges, and become almost irremovable. The growth of this kind of oligarchy is supported by Michels by his concept of the mass mind. The Majority of human beings according to Michels are apathetic, indolent, and slavish, and are permanently incapable of self-government. They are susceptible to flattery, and obsequious in the presence - of strength. Leaders easily take advantage of these qualities to perpetuate themselves in power. They employ all kinds of methods oratory, persuasion, playing upon sentiments in order to fool them. Once the leaders reached the pinnacle of power, nothing could bring them down. "If laws are passed to control the dominion of leaders, it is the laws which gradually weaken, and not the leaders." Revolutions sometime occur in history and tyrants are disposed, but new tyrants arise, and the world goes on as before.

\section{Gaetano Mosca (1858-1941)}

While Pareto was basically a sociologist and a psychologist, Gaetano Mosca who further developed the theory of political elites as well as the concept regarding the circulation of elites, was basically a political scientist. Strongly repudiating the classification of governments into monarchy, aristocracy and democracy which Aristotle had initiated, he 
asserted that there was only one kind of government, namely oligarchy. "In all societies - from societies, that are very meagerly developed and have barely attained the dawning's of civilization, down to the most advanced and powerful societies-two classes of people appear a class that rules and a class that is ruled. The first class, always the less numerous, performs all political functions, monopolizes power and enjoys the advantages that power brings, whereas the second,' the more numerous class, is directed and controlled by the first, in a manner that is now more or less legal, now more or less arbitrary and violent and supplies the first, in appearance at least, with the instrumentalities that are essential to the vitality of the political organism. "The larger the political community", he adds later, "the smaller will be the proportion of the governing minority to be governed by, and the more difficult it will be for the majority to organise for reaction against the minority." Like Pareto, Mosca also believed in the theory of the circulation of elites. The distinguishing characteristic of the elite being "the aptitude to command and to exercise political control", once the ruling class loses this aptitude and people outside the ruling class cultivate it in large numbers, there is every possibility that the old ruling class will be deposed and replaced by the new one. Mosca believes in a kind of law, that the governing elite, in course of time, is not able to provide the necessary services to the masses, or the services they continue to provide are no longer regarded as valuable, or a new religion arises, or some similar changes take place in the social forces pervading the society, and' that in 'such cases change becomes inevitable. Mosca takes up not only the psychological reasons for the change, as Pareto had done, but also the sociological reasons. He is able to establish some relationship between the changes in social circumstances and individual characteristics. New interests and ideals are formulated in society, new problems arise, and the process of circulation of elites is accelerated. Mosca also is not so critical of idealism and humanitarianism as Pareto, and has a somewhat modest view of the use of force. He prefers a mobile society and change through persuasion. He also advises the governing elite to bring about gradual alterations in the political system in order to make it conform to changes in the public opinion. .

Mosca explains the rule of the minority over the majority by the fact that it is organized, whereas the individual in the majority stands alone before it, and also by the fact that the minority is usually composed of superior individuals. While Pareto had mentioned the fact of the political class being composed of distinct social groups, Mosca examines more closely the composition of the elite, and recognizes the role of certain "social forces', the expression he uses for Pareto's 'non-governing elites', in balancing and limiting the influence of other 'social forces'. Mosca also introduces the concept of the 'sub-elite', composed practically of the whole new middle class' of civil servants, managers of industries, scientists and scholars, and treats it as a vital element in the government of society. "The stability of any political organism", he writes, "depends on the level of morality, intelligence and activity that this second stratum has attained."

Mosca attaches a great deal of importance to what he calls the "political formula". Mosca's "political formula" is equivalent to Pareto's "derivations". In every society, he believes, the governing elite tries to find a moral and legal basis for its being in the citadels of power and represents it as "the logical and necessary consequence of doctrines and beliefs that are 
generally recognized and accepted". The political formula may not, and generally does .not, embody absolute truth. It may as well be merely a plausible myth which is accepted by the people. Mosca is not prepared to accept that it is nothing but plain and simple fraud cleverly contrived by the ruling class in order to dupe the masses into subjection The fact that the policies of the ruling class, even though formulated in its own interest, are covered in a moral and legal garb satisfies, according to Mosca, a definite social need and gratifies a deeply felt human requirement that man should be governed on the basis of some moral principle, and not by mere physical force. It also serves as a factor in the unification of political institutions, peoples and civilizations. Mosca would, therefore, regard it as an instrument of moral cohesion.

\section{Concept and Theory Applicability}

The involvement of the Nigeria elite in the Nigerian project predates independence in 1960. Nationalist like Sir. Amadu Bello, Chief Obafemi Awolowo, Sir. Tafawa Balewa, Dr. Nnamdi Azikwe, Sir. Herbert Macauley, Mallam Aminu Kano, Chief Anthony Enahoro, among others where the foremost political elite in Nigeria. They were all involved in the struggle for Nigeria's Independence. The Nigerian governing elite as continuously revolved around the political elite, military elite, and the religious/traditional elite. After independence in 1960, the political elite were in charge of leadership from 1960-1966 before the military elite first ventured into politics through a coup d'état. Between 1990 and 1966, prominent political elite were in charge of the affairs of their various regions i.e. Western Region, Eastern Region and Northern Region (Ola \& Tonwe, 2009).

The military held sway of the leadership of the country from January 1966 to October 1979. Within this period usually referred to as the first coming of the military, there were three military coups and counter coups. The General Johnson Thomas Umumakwe Aguiyi-Ironsi coups on $15^{\text {th }}$ January, 1966; General Yakubu Gowon counter coup in July 1966; The General Muritala Ramat Mohammed coup on $30^{\text {th }}$ July, 1975; the failed coup of Lieutenant Colonel Buka Dimka on $13^{\text {th }}$ February, 1976 and the continuation of the Muritala/Obasanjo's regime till $1^{\text {st }}$ October, 1979. The country witnessed civil rule under the leadership of Alhaji Shehu Shagari as the first elected Executive President between $1^{\text {st }}$ October, 1979 to $30^{\text {th }}$ December, 1983. The second coming of the military in Nigerian politics began on $31^{\text {st }}$ December, 1983 and ended on $29^{\text {th }}$ May, 1999. Also, within this era there were four military regimes. The General Muhammadu Buhari regime between $31^{\text {st }}$ December to $27^{\text {th }}$ August, 1985; General Ibrahim Badamosi Babangida from $27^{\text {th }}$ August, 1985 to $31^{\text {st }}$ July, 1993; the General Sani Abacha regime between $17^{\text {th }}$ Novermber, 1993 to $8^{\text {th }}$ June, 1998; the General Abdulsami Abubakar's regime between $9^{\text {th }}$ June 1998 and $29^{\text {th }}$ May, 1999 was the only military government that did not come into power through a coup. His predecessor died and the Military Council appointed him as the Head of State. He returned Nigeria to civil rule on $29^{\text {th }}$ May, 1999 after several failed and aborted attempts by previous military governments. It is important to note that, there was an Interim Government headed by Chief Earnest Shonekan between $31^{\text {st }}$ July, 1993 to $17^{\text {th }}$ Novermber, 1993 when General Babangida stepped aside. Although, scholars have argued that it was the military that stepped aside due to the tension in the protests across the country occasioned by the annulment of the $12^{\mathrm{TH}}$ June, 1993, 
Presidential elections by the Military Junta. The elections is still by adjudged as the free and fairest in Nigerian post independence history till date.

According to Agagu; (2011) since independent till date, the Nigerian political landscape have largely been dominated by the military elite who held swayed between 1966 and 1979 and 1983-1999. The political elite were in charge of Nigerian affairs from 1960-1966 (the first republic), 1979-1983 (second republic), 1990 to 1993 (the third abortive republic) and 1999 till date (fourth republic) (Adeniyi 2010; Agagu 2011).

The elite theory best explains Nigeria leadership experience since independence which has been dominated largely by "recycled" politicians and retired military officers. The current democratically elected president, General Muhammedu Buhari was a Military Head of State in 1983 which ushered in the second coming of the Military in Nigerian politics. He was Minister/Federal Commissioner for Petroleum and Natural Natural Resources under the Murtala/Obasanjo Military Regime. General Buhari was as the Head of Petroleum Trust Fund under General Sani Abacha's Military Regime and several after, he is the democratically elected President of Nigeria. The story is not different for General Olusegun Obasanjo who was also a former Military Head of State between 1976 and 1979; and historically handed over power in 1979 to civilian government. General Olusegun Obasanjo was elected the democratic President and served between 1999 and 2007. Senator Olusola Saraki was the Nigeria Senate Leader in the Second Republic while his son, Senator Olubukola Saraki become a two term Executive Governor of Kwara Sate and Senate President in the Fourth Republic.. Senator David Mark was also former State Administrator and a Minister under the General Ibrahim Babangida Military Regime between 1985 and 1993. David Mark returned to Nigeria's politics in 1999 as a Senator and served as a two term Senate President between 2007 and 2015. Etebom (2009) opined that Nigerian elites, both military and political, has continued to dominate the Nigerian political landscape contradicting Mosca's postulation of the elite circulation. Etebom argued that in place of elite circulation, the Nigerian experience had been more of elite replacement and elite regeneration. The Religious elite are among the wealthiest Nigerians (Bishop David Oyedepo, Pastor E..A. Adeboye, Sheik Ibrahim El Zaksaky, Pastor Sam Adeyemi amongst mang others); they weigh lots of influence on the governing elite as members of their places of worship either as Christians or Muslims. The Clergy in Nigeria have large followership but this has not really translated led to good leadership in the country despite the teachings in the holy books.

From the behavioral definition of leadership which emphasis clear vision, sharing the vision with followers, providing information and communication, coordinating and balancing the conflicting interest of all stakeholders; and the classical elite theory postulations that the elite control political power, economy and the control of flow of information as well as influence decision making process. The governing elite have largely failed in this regard. (Heywood 2013; Varma 2005). The trust of Nigerian leadership crisis is that the governing elite have not exhibited the leadership attributes as propagated by Heywood, Varma and other scholars on leadership. This leadership crisis is not peculiar to Nigeria as most African countries still face these challenges of leadership. Successive governing elite in Nigeria (political and military) have not been able to establish a national vision that is realistic and achievable through which 
the citizens can easily pursue and achieve sustainable development and good governance. The Nigerian governing elite has been alleged of corruption, ethnicity, selfishness, greediness, constitutional abuse as well as subversion of democratic tenets.

\section{Conclusion and Recommendations}

The Nigeria governing elite which comprises of the military elite, political elite, religious elite have not use their vantage positions to pursue national interest which would have led to socio-economic development and national integration. History has also shown that the Nigerian governing elites do not learn from the past, they pursue self seeking and sectional agenda. Kolawole (2011), argued that the post-colonial Nigerian state is still battling with forces democratic consolidation decades after independence. He opined that ordinarily, there ought to be a correlation between the age of a nation and the level of democratic consolidation. But the Nigerian experience has not justified such hypothesis. The recent revelations of massive corruption by previous administrations as revealed by Economic and Financial Crimes Commission revealed the crops and attitudes of the governing elites in the country. The high level of insecurity across the country vis-a-vis kidnapping, insurgency, terrorism; the high level of unemployment, poor state of infrastructural facilities, division along political and ethnic affiliations, agitations by the various ethnic groups in the country among others have shown that the governing elite in Nigeria have not delivered on quality leadership thereby failing in its responsibility.

The study recommended a return back to Regionalism which was delivered to the Nigerian state as independence by the Britain, true federalism including fiscal federalism, strict adherence to the provisions of the constitution, strengthening of public institutions through funding without government influence, repositioning of the civil service, national conference to agree on national agenda and vision as a nation and a constitution review to accommodate the above with stringent penalties for corrupt leaders. The study strongly recommend defined Autonomy for Local Government as against what is been practiced in the country to bring governance closer to the grassroots which is the bedrock of national development. The study concluded by arguing that, Nigeria have the capacity to be a leading nation in Africa and a voice in the international community of nation if gets its leadership question alright considering its vast landscape, population and material resources.

\section{References}

Adeniyi, P. (2010). Nigeria Yesterday, Today and Tomorrow, Daily Graphics Nigeria Ltd, Ibadan.

Agagu, A. A. (2011). Theory and Practice of Local Government, Policy and Consultant Ltd, Akure.

Akindele S. T. (1999). Traditional Elite Theory: A Critical Analysis of its Ideological Class with Democratic and Marxist Theories of Society.

Appadorai, A. (1975). The substance of Politics, Oxford University Press, New Delhi.

Etebom, J. M. (2019). Dynamics of Local Council Elections and Good Governance in South 
West, Nigeria, Unpublished PhD Thesis.

Heywood, A. (2013). Politics, Palgrave Macmillan, England.

Joseph, R. (1991). Democracy and Prebanded Politics in Nigeria; The Rise and Fall of the Second Republic. Cambridge Press, New York.

Kolawole, D. (2011). Nigeria: The Struggle for Democratic Consolidation in a Post-Colonial State in Agagu, A.A. \& Ola, R.F. (ed) Development Aganda of the Nigerian State.

Mazi Mbah, C. C. (2006). Political Theory and Methodology. Rex Charles and Patrick Ltd, Enugu.

Modupe, A., \& Olakunle, O. (2016). Governance and The Challenges of Leadership in Nigeria, International Journal of Politics and Good Governance, 7(1).

Obah-Akpowoghaha, G. O. (2013). Political Parties and the Challenges of Democratic Consolidation in Nigeria accessed at https://www..semanticscholar.org

Odock, C. N. (2006). Democracy and Good Governance. Lagos: NOUN

Ogunmilade A., Nwoko, G. C., \& Akhigbe, O. J. (2017). The Challenges of Leadership and Governance in Nigeria, Research on Humanities and Social Sciences accessed at https://www.iiste.org

Ola, R. O., \& Tonwe, D. A. (2009). Local Administration and Local Government in Nigeria. Trust Publishing, Nigeria.

Ugwu, O. (2015). Democracy and governance in Nigeria Challenges and Prospects, Global Journal of Human-Social Science. F.Political Science, 15(3).

Varma, S. P. (2005). Modern political Theory, Publishing House PVT Ltd, New Delhi, India

\section{Copyright Disclaimer}

Copyright for this article is retained by the author(s), with first publication rights granted to the journal.

This is an open-access article distributed under the terms and conditions of the Creative Commons Attribution license (http://creativecommons.org/licenses/by/4.0/). 